\title{
FACTORS AFFECTING HUMAN RIGHTS IN KHYBER PAKHTUNKHWA, PAKISTAN
}

\author{
Hashmat Ullah Khan \\ PhD Scholar, School of International and Public Affairs, Jilin University China \\ Email: hashmat.kpk@gmail.com \\ Dr. Yan Zhen \\ Professor, School of International and Public Affairs, Jilin University China \\ Email: yanzhen1357@126.com \\ Muhammad Naeem \\ PhD Scholar, School of Law, Zhongnan University of Economics and Law, China \\ Email:paktoon.naeem@gmail.com
}

\begin{abstract}
In Khyber Pakhtunkhwa the situation of human rights is comparatively worse. Factors affecting human rights in this province include failure to guarantee good governance, growing poverty, illiteracy, violence, terrorism, worsening security, social injustice, political instability, and economic turmoil. These factors have been affecting adversely the human rights. To ensure human rights in the province, the execution of international human rights laws needs to be implemented. It is required to ensure good governance, peace and stability to ensure viable environment, provision of sustainable and quality education and reduce poverty. Unless the favourable environment be provided to the people at large, human rights violations may be continued. This paper attempts to know about the factors affecting human rights in the province and present some solid recommendations and policy options.
\end{abstract}

Keywords: Khyber Pakhtunkhwa, Human Rights Violation, Universal Declaration of Human Rights, Injustice

\section{INTRODUCTION}

Human Rights are the basic human rights of every human in the world from birth to death. Human Rights ensure favorable, good and attractive living environment for human-being which guarantee quality life, equality, dignity, justice and fairness. Human beings are entitled to some basic rights called human rights, irrespective of age, gender, race, color, faith, religion or any other discrimination. These rights are absolute, inalienable, innate, and universal based on human being dignity. Furthermore, these rights are definite in theory protected by the concerned state's constitution and practically safeguarded by the 
courts (Gill, Phull and Chachar, 2017). Because of emergence of consciousness and awareness in human being spanned over the centuries, the concept of human rights developed and acknowledged throughout the world. Human Rights is now a worldwide concept that all humans are entitled to the right to life, health, freedom, liberty and shelter. Some indispensable principles expressed by Human Rights like equality, non-discrimination and fairness are related with numerous legal and spiritual codes which can be found throughout known history of mankind and happened in different shapes in various areas. Human Rights mainly developed from the British Magna Carta, Bill of Rights, the French Declaration of Rights and US Declaration of Independence (Košir and Lakshminarayanan, 2021). The Human Rights protection concept is mostly appeared after the massive violation of human rights in the first and second World wars. Thus, these are basic rights necessary for all human beings and recognized by International Law (Xin and Yi, 2011). Every individual of a society needs to live a dignified and satisfied life for which some standardized living conditions are necessary required everywhere. These conditions and quest for dignified and satisfied life gave birth to human rights and its protection. Therefore, the human rights need, and importance are universal.

To guarantee these fundamental human rights, the "Universal Declaration of Human Rights" was adopted on December 10, 1948 by the member states of UN (Wotipka and Ramirez, 2008). All people are entitled to these rights irrespective of gender, age, color, race, language, nationality, religion, ethnicity or any other status (Esteves, A.M., et.al., 2017), but the limited understanding of human rights creates a lot of problem (Sendroiu, 2019). In the Khyber Pakhtunkhwa province of Pakistan, the human rights condition is adverse. There are several factors affecting the rights of its inhabitants including lack of good governance, growing poverty, violence, terrorism, worsening security, social injustice, political instability, and economic turmoil. Khyber Pakhtunkhwa is the then North-Western province of Pakistan covered an area of 101741 square kilometers and composed of 30,523,37 population (Census, 2017) largely Pakhtuns by ethnicity. Pashto is spoken by most of the population, however, Seraiki, Hindko, Khowar Urdu and Persian etc. are also regional languages. 


\section{EVOLUTION OF HUMAN RIGHTS}

Though the idea of human rights emerged in $17^{\text {th }}$ and $18^{\text {th }}$ century but after Second World War it became very popular especially after the Holocaust. The term "Human Rights" was first used by a French scholar Thomas Paine (Kamruzzaman and Das, 2016). In promotion of human rights the teaching of different religions, Hammurabi in Babylon 1772 BCE (Ishay, 2008), British Magna Carta 1215 (Chodhry, 1992), Petition of Right 1628, Bill of Rights 1689, the writing of scholars like John Lock and Hobbs, US Declaration of Independence 1776 (Kaur, 2014), Geneva Conventions and the Second World War and the establishment of UN internationalized the human rights (Marks, 2016).In modern era, the Universal Declaration of Human Rights (UDHR) adopted on December 10, 1948 by the members of the United Nations is considered as milestone in this regard. It set up a common standard of rights for all people without any discrimination for the first time (Gautam, 2000). There are total 27 human rights determined by UDHR and DGICCP. The impact of this Universal Declaration of Human Rights has been extensive. The principles and rules of this declaration have been incorporated into the constitutions of more than 185 countries. Although this human right declaration is not a legally binding document but acquired the position of customary international law. Moreover, the International Bill of Human Rights, the International Covenant on Political and Civil Rights, International Covenant on Social, Economic and Cultural Rights and many other Convention to safeguard the right of people and guarantee equality are adopted. Many inter-governmental organizations and UN special agencies are also established to protect human rights including UN Commission on Human Rights, ILO, UNICEF, UNIFEM etc.

As concerned human rights in Pakistan, the idea was first of all put forward by Quaid-e-Azam, the Founder of the Nation, in his first presidential address to the first Constitutional Assembly of Pakistan on August 11, 1947. He said that "we are starting in the days where there is no discrimination or distinction among Pakistanis. We all are the equal citizens of one country" (International Human Rights Observer).

\section{PREVAILING CONDITIONS OF HUMAN RIGHTS IN KHYBER PAKHTUN KHWA}

The Constitution of Pakistan guarantees basic human rights such as, security of life, property, honour, safeguard from unlawful detention and arrest, enforced labour, fair trial, religious freedom, 
movement, assembly and association, freedom of speech and freedom of business, trade and choosing of profession. The constitution of the state provides all these rights without any discrimination across the country but the people of this province are facing many grave human rights issues and violations that include gender based discrimination, domestic violence against women, honour killings, terrorism, targeted killings, forced disappearance, extra-judicial imprisonment and murders, torture, sectarian violence, lack of due legal process, poor execution of laws, insecurity, lack of health facilities, lack of education, sexual harassment, child labour, violations of privacy rights, torture and attacks on those who are speaking and writing against those violating human rights and those who are working for the cause of human rights. Though there are many federal and provincial laws and regulations to ensure the rights of people and provide them good living conditions, but the basic issue deals with the implementations of these laws and regulations. Therefore, their rights are not safeguarded and subject to violations.

The existing prevailing situation in the province is affecting the rights of all its citizen comprehensively. The human rights are being violated very frequently due to many reasons. The violations are being reported in electronic as well as in print media regularly. In the province, the capitalists have shaped an unfair system for the poor class and lower middle class which empowered the upper-class to influence their fate. Due to this there is widespread poverty across the province which is a main cause of violating human rights of the concerned people. Women are also unable to get equal status, opportunities, fair treatment, even failed to get just advantage of their labor. Their social status is subject to widespread gender-based discrimination. There is dissonance in the law. Though according to Pakistani laws, male and female are equal but due to socio-economic situation, fundamentalism, feudalism, lack of education, lack of awareness, tribal norms and tradition female are subject to gender discrimination. In different parts of Khyber Pakhtunkhwa, female are also facing domestic violence. On regular bases domestic violence is being recorded and every year a large number of female are being killed. They are facing many kinds of sacrifices but receiving very less than their share and even used as scapegoat when hostilities and revenges are resolved in some areas of this province. Majority people 
are living in rural areas, excluding those living in main towns, have no appropriate health facilities, a large number of their kids are out of school mainly because to lack of opportunities and poverty, a huge number of its inhabitants lost their lives in war on terror and sectarian conflicts, facing the issues of fair trial and illegitimate detentions and arrests and even facing forced-disappearance. In such a situation it became very difficult to ensure basic human rights of the citizens. There are many organizations and governmental initiatives to protect the basic rights of the people but yet not fully successful.

There are also many legal issues and challenges to human rights in every country of the world (Rodrigues, 2020). Therefore, states are making laws, rules and regulations to ensure human rights and provide a good living environment to its citizens. Article 2 to 40 of the 1973 Constitution of Pakistan deal with basic human rights and its principles. At the provincial level the provincial government established the Directorate of Human Rights which is working for promotion and protection of human rights and committed to takes all necessary actions which are notable indications for the improvement of the condition of human rights in the province. Likewise, in recent years the provincial government of Khyber Pakhtunkhwa has also made several laws for the protection of human rights. These laws are:

- Khyber Pakhtunkhwa Child's Protection Welfare Act, 2010.

- Khyber Pakhtunkhwa Harassment of Women at Workplace Act, 2010.

- Khyber Pakhtunkhwa Enforcement of Women Ownership Rights Act, 2012.

- Khyber Pakhtunkhwa Domestic Violence Act, 2012.

- Khyber Pakhtunkhwa Elimination of Custom Ghag Act, 2012.

- Khyber Pakhtunkhwa Provincial Watch Committee on Sexual Harassment Act, 2012.

- Khyber Pakhtunkhwa Promotion and Protection of Human Rights Act, 2014.

- Khyber Pakhtunkhwa Protection of Communal Properties of Minorities Act, 2014.

- Khyber Pakhtunkhwa Prohibition of Employment of Children Act, 2015. 
The more worrying issue is the reality that the situation of human rights in the province has not improved; but, it is relatively becoming worse. As poverty level in Khyber Pakhtunkhwa grows as well as risks to the lives of the people are also rising which are creating many of challenges of human rights. Though, Pakistan is a signatory of the Universal Declaration of Human Rights, but majority of its conditions are yet to be executed and such is the case of other International Covenants of Human Rights signed by Pakistan like Covenant on the Rights of the Child and Covenant against Torture. Several basic provisions of these human rights covenants including the right of health, education, freedom, employment and dignity are obviously not implemented.

\section{FACTORS AFFECTING HUMAN RIGHTS}

The condition of Human rights in the Khyber Pakhtunkhwa province is very bad and it is deteriorating on regular basis. There are numerous factors including bad governance, growing poverty, illiteracy, violence, terrorism, worsening security, social injustice, political instability, and economic turmoil that affect human rights and hamper the way to protect it. There is widespread deprivation in the society playing very negative role in this regard. The long eras of dictatorship in the country as well as in the province have stopped the development of democratic norms that caused less empowerment of citizens which ultimately deprived citizens from free thinking, awareness, education and social mobility. The deprivation is very serious for those who are also at risk based on their poverty, illiteracy, gender, age or spiritual beliefs leaves them vulnerable and weak to save themselves against diverse atrocities.

Another factor that affects the human rights in the province is the illiteracy. In fact, education is the key element plays a crucial function in creating awareness in citizens about their due human rights and its safeguards through legal methods. But the ratio of education is also low in this province. About 65 percent female and 30 percent male residents are uneducated (Hussain, 2015). An uneducated individual even does not know about its due rights then how it will secure. This is not only limited to grown people, but a huge number of children is also out of school even today, because there are inadequate educational institutes as compared to the number of school going kids. The total number of children aged between 0 and 17 is 12.08 million; girls 5.722 
million (47.37\%) and boys 6.358 million (52.63\%) (Dawn, May 2, 2018). Recently, the Khyber Pakhtunkhwa Elementary and Secondary Education Department has conducted a survey of "out of school children". The survey recorded that across the province 1.8 million children are out of school. It is 23 percent of the total number of the children of 5-17 years of age. It is out of school mostly due to poverty and secondly lack of nearby school. Across the province there is total 28176 Schools and Colleges having 4450057 enrolled students and 130662 teaching staff and 19 universities having 84680 enrolled students (22932 girls and 61748 boys) and 4086 teaching staff (Mehmood, 2017). Apart from these there is also 6743 private Schools in the province having 1510646 enrolled students (468386 female and 1042260 male), total teaching staff in the private schools is 85325 (44466 Female and 40859 Male) (Mehmood, 2017).

Alongside another striking factor which is affecting most of human rights in the province is relative poverty. It added much to human rights challenges. It is facing second highest poverty rate in Pakistan. The rate of poverty in Khyber Pakhtunkhwa province is 49.2\%, while in Punjab it is $31 \%$, in Sindh and Gilgit Baltistan it is $43 \%$, in Balochistan it is $71 \%$ and in Azad Jammu and Kashmir it is 25\% (UNDP, 2016). Poor people are facing many complex problems. They have the problems of poor malnutrition and health facilities, shortage of clean water for drinking, poor work environments and problem of schooling of their children. Poverty is decreasing in Pakistan but according to a survey finding poverty is decreasing in this province very slowly as compared to other provinces of the country. In addition to the common economic crisis in the country, which is essentially also affecting Khyber Pakhtunkhwa, there is also the problem of growing food shortage, which is linked to the increase in prices of food elements. Capitalists and investors as well as lack of opportunities have created an unfair financial structure for the poor people and labor class of the province which empowered the upper class to control their fate. Therefore, the rights of the labors and other poor are usurped. The execution of labor laws also remains very poor and futile because of neglect and lack of determination of the government.

Health is considered another concern of human rights (Asgary and Segar, 2011). Its condition in the province is not satisfactory. 
There is insufficient number of doctors and hospitals as compared to the number of patients. The government is spending only $4.45 \%$ annually of its budget on health which is very low (Ali, 2017). This is less than most of the Asia countries. In the hospitals and Basic Health Units across the province there is poor and inadequate facilities and services. Rural Health Centers and Basic Health Units are either not partly operational or lack of qualified staff and facilities. This issue is not limited to only this province of Pakistan but worldwide annually 18 million people die because of lack of health facilities (Ma et al., 2020). The forced migration also created health related issues and lack of access to this basic human right (Ruchman, 2020). The forced migration took place in many areas of Khyber Pakhtunkhwa due to rise of terrorism, war of terror and natural disasters which created a lot of health problems to the displaced people.

Another issue is the violation of women rights. In most areas of the province women are being highly abused and mistreated in economic cultural, social and political matters. The society is patriarchal and male-dominated, where women is considered inferior to men. They are also subject to honour killing due to many traditions and customs. The data of Human Rights Commission of Pakistan shows that in the last five years 390 cases of honor killing were registered in the province, of whom 345 were female whereas 45 were male (News Lanes Pakistan, April 1, 2017). It is also a fact that many cases may have gone unreported occurred in remote areas because of tribal customs and self-proclaimed execution of Islamic decrees by the power structure of tribes. Mostly females are also mistreated due to gender. The government and civil society are unable to protect female being weaker to the strong and prevailing customs and traditions (Jahangir, 1999). There is honor killing cases. The society gives serious penalties and even kill females in honor cases but in most cases leaving the concerned males free without punishment. Violence against females including rape, honor killing, forced marriage, domestic violence, and acid attacks are the serious challenges facing by the females of the province. Just only in 2017, across the province 180 cases of domestic violence were recorded, included 94 females were killed (Human Rights Watch Report, 2018). Females have been symbolized as commodity for the male in tribal structure (Gill, Phull and Chachar, 2017). They are using as safe goat in resolving tribal 
disputes in tribal areas of the province. Another issue is Child marriages. Though the constitution of the country determined 18 years of age for marriage, but it is violated frequently in this province and became one of the serious issue. According to the UN Children's Emergency Fund, 21 percent of females in Pakistan are wedding before the age of 18 years (Human Rights Watch, 2018). Their participation and involvement in politics is also very low, even in many parts of the province females are not allowed to cast vote. To safeguard a minimum participation of women in legislature, seats are reserved for them.

Children are also subject to human rights abuses and violations. Though Pakistan has signed the ILO's convention on child labor, but children labor is still continue across the country including in Khyber Pakhtunkhwa province even in risky sectors like workshops and coal mining etc. child forced labor practices are also recorded in this province. The $18^{\text {th }}$ amendment in the constitution dissolved the "Federal Ministry of Labour and Manpower", which resulted in the decentralization of this subject to the provinces, but this devolution of power also couldn't control the violations of the rights of labors. Still salaries of labors are very low. Though the government has increased the minimum wages to 15,000 rupees, but its implementation is still a dream.

Terrorism has been the new heinous issue of Khyber Pakhtunkhwa. It is another crucial factor which badly affect human rights across the province. Thousands of civilians have lost their lives during the rise of terrorism and anti-terrorist operations in the province and millions of people were internally displaced even many of them displaced several times. Government settled them in the migrated zones but didn't rehabilitate them, which severely affected the human rights of the displaced people. The cruelty by terrorists against the people of the province and violations of their human rights are still continuous. Sometime counterterrorism itself also violating human rights in the area (Abozaid, 2020). It added to the culture of disorder and anarchy in the province. The terrorist groups have been killing those who are opposing their ideologies as well as reporters who are writing against them and reporting their cruelties. The problem of forced disappearances is also severe across the province. Illegal arrest and maltreatment during custody are common (Report of the Working 
Group on Enforced Disappearances, 2013). Environments of some jails and detention centers are also not appropriate which is influencing the human rights of detainees. Detainees are also confronting overcapacity, poor health services and unhygienic and inappropriate food issues which are the basic rights of all humans without any discrimination.

Another issue is the violations of the rights of transgenders. Their lives are not safe, facing brutal attacks in this province. In fact, it is not limited to only Khyber Pakhtunkhwa province but throughout Pakistan they are not safe. Everywhere at home and in the society, they are miss-treated, abused and consider as second-class citizens of the states. In order to protect their human rights, a law passed by the legislature and a distinct category for them as Khawaja Siras was also incorporated in the 2017 Census for the first time, but it also couldn't any positive change the protection of their status in the society of protect their lives. This is a very serious issue of the society and the community is affecting badly. A number of transgender were killed and injured. In recent years crimes against the transgender are notably increased. They are subject to different kind of harassment and discriminations in the society of Khyber Pakhtunkhwa.

Another human right which is access to news and information about events accruing around is violating on the name of censorship. The freedom of press was restricted mostly during military regimes. But even at present democratic regime there are many restrictions and limitations on media and access to information. The succeeding democratic governments attempted on many times to control both print and electronic media. This is also the suppression of basic liberty of citizens. In fact, the freedom of media is a very important thing in progressive societies aimed to create awareness and socialization even it educates people about their due human rights. Therefore, this lack of access to news also creating hurdles in the way of securing other human rights.

\section{CONCLUSION}

The condition of human rights in the Khyber Pakhtunkhwa province of Pakistan is not satisfactory. The human rights of the people are not ensured and are being flouted on daily bases. There are several factors and reasons which are affecting the human rights of the people of this province. These factors are poverty, terrorism, law and 
order issues, bad governance, not implementation of law regarding the human rights, illiteracy, discrimination and social injustices deeply rooted in the society. The human rights violation is a critical dilemma in the province. Many laws are made by the government to ensure human rights but to no avail. The most worrying issue is the reality that the condition of human rights is not improving but comparatively becoming worse. Though there is many laws and regulations, and the country is also signatory of different human rights conventions, but those laws and conventions are yet not executed fully. If only poverty controlled, and the ratio of literacy increased then the condition of human rights can significantly improve across the province.

\section{RECOMMENDATIONS}

1. In Khyber Pakhtunkhwa a task force is required to control the violations of human rights.

2. One of the main factor affecting human rights in the province is poverty. Government must take all required measures to reduce the poverty level by creating durable economic opportunities without any discrimination across the province. The province is full of natural resources and has better opportunities to trade with Afghanistan, China and Central Asian countries. It needs the good attention of the government.

3. Democratic institutions should be strengthened in the province to ensures accountability, key for the human rights protection. Experience proves that democracy is more helpful in promotion and protection of human rights as compared to other types of regime.

4. For the protection of human rights awareness about the due rights is very necessary. It is education which creates awareness about rights, therefore increasing the ratio of literacy in the province is essential. Moreover, out of school children should be in school and street children should be off street. Child labor should also be strictly banned and government should provide financial support to such children to get education.

5. Most of the women rights are violating due to lack of education, blind compliance to the century old traditions and customs and lack empowerment. To guarantee their rights it is necessary to educate them, empower them and stop blind compliance to those centuries old unjust traditions and customs which lead to ignore 
their rights. The elimination of parallel tribal judicial mechanism, domestic violence, gender-based discrimination and economic exploitation of women in the society need to stop.

6. Eradication of all types of terrorism, extremism, fundamentalism and sectarianism are also needed to stop. In addition, to bring peace, prosperity and stability it is also required for every resident of the province to stand-up against terrorism, extremism, fundamentalism and sectarianism.

7. To guarantee the rights of minorities and religious freedom it is necessary to bring awareness among people. It is necessary to teach and convince them that respect of minorities is required in Islam.

\section{REFERENCES}

Abozaid, A. M. (2020). Counterterrorism strategy and human rights in Egypt after the Arab uprising: A critical appraisal. Aggression and Violent Behavior, 51(2):101-115.

Asgary, R. and Segar, N. (2011). Barriers to health care access among refugee asylum seekers. Journal of Health Care for the Poor and Underserved, 22(2):506-522.

Census-2017. http://www.pbs.gov.pk/sites/default/files/PAKISTAN\%20TEHSIL \%20WISE\%20FOR\%20WEB\%20CENSUS_2017.pdf

Chodhry, Z. I. (1992). Introducing Human Rights: Concept and Practice, International Review of Humanism and Human Rights, 1:49.

Esteves, A. M. et.al., (2017). Adapting social impact assessment to address a project's human rights impacts and risks. Environmental Impact Assessment Review, 67:73-87.

Gautam, A. K. (2000). Human Rights \& Justice System. New Delhi: A. P. H. Publishing Corporation.

Gill, F., Phull G. M. and Chachar, A. A. (2017). Human Rights Violations of Labour and Women in Pakistan. Biannual Research Journal Grassroots, 51(1):228-236.

International Human Rights Observer Islamabad-Pakistan. Pakistan Law on Human Rights. www.ihro.org.pk

Ishay, M. (2008). The History of Human Rights: From Ancient Times to the Globalization Era, With a New Preface. New York: Norton and Co.

Kamruzzaman, M and Das, S. K. (2016). The Evaluation of Human Rights: An Overview in Historical Perspective. American Journal of Service Science and Management, 3(2):5-12.

Kaur, S. (2014). Historical Development of Human Rights. Journal of Social Sciences Research, 6(2):996-999. 
Košir, S. and Lakshminarayanan, R. (2021). Inclusion of generations of human rights in social Science textbooks. International Journal of Educational Development, 80:1-11.

Ma, X. et al. (2020). Human rights-based approach to global surgery: A Scoping Review. International Journal of Surgery, 82:16-23.

Marks, S. P. (2016). Human Rights: A Brief Introduction. Harvard University Press.

Mehmood, T. (2017). Development Statistics of Khyber Pakhtunkhwa-2017. Bureau of Statistics Planning \& Development Department Government of Khyber Pakhtunkhwa. www.Kpbos.Gov.Pk

Report of the Working Group on Enforced or Involuntary Disappearances on its Mission to Pakistan (2013, February 26). Retrieved: https://www.refworld. org/docid/513715d02.html

Rodrigues, R. (2020). Legal and human rights issues of AI: gaps, challenges and vulnerabilities. Journal of Responsible Technology, 4:1-5.

Ruchman, S. G. (2020). A toolkit for building medical programs for asylum seekers: Resources from the Mount Sinai Human Rights Program. Journal of Forensic and Legal Medicine, 75:1-7.

Sendroiu, I. (2019). Human rights as uncertain performance during the Arab Spring. Poetics, 73:32-44.

UNDP. (2016). Retrieved:

http://www.pk.undp.org/content/pakistan/en/home/presscenter/pressreleas es/2016/06/20/pakistan-s-new-poverty-index-reveals-that-4-out-of-10pakistanis-live-in-multidimensional-poverty.html

United States Department of State Bureau of Democracy, Human Rights and Labor, Country Reports Pakistan on Human Rights Practices for 2017. Retrieved: https://www.state.gov/reports/2017-country-reports-on-humanrights-practices/

Wotipka, C. M. and Francisco, O. R. (2008). World society and human rights: an event history analysis of the convention on the elimination of all forms of discrimination against women. The Global Diffusion of Markets and Democracy, 3096:303-343.

Xin, H. and Yi, U. (2011). The conception of three generations of human rights: sources, debates and evaluation, Journal of Taishan University, 4(12). Retrieved:http://en.cnki.com.cn/Article_en/CJFDTotal-TASZ201104012. htm

Jahangir, A. (1999, July). HRCP Newsletter.

Hussain, A. (2015, March 2.). Education System of Pakistan: Issues, Problems and Solutions. IPRI Review.

News Lanes Pakistan, April 1, 2017.

Ali, M. (2017, June 8). 'KP Budget 2017-18', Dawn.

Human Rights Watch. (2018, January). 'Country Summary Pakistan'. 